\title{
Institutional Investors, Earnings Management And Mispricing Of Accruals: Evidence From China
}

\author{
Zhen Zeng, Xi' an Jiaotong University, China \\ Peiyu Ou, Xi'an Jiaotong University, China \\ Bin Li, Xi'an Jiaotong University, China
}

\begin{abstract}
This study examines the role of institutional investors in the pricing of normal accruals and discretionary accruals using the firms listed in the Chinese A-share Market. The results show that significant overpricing of discretionary accruals exists for individual investors and institutional investors, suggesting that they are both misled by the earnings management, while institutional investors are associated with significantly less overpricing. With respect to normal accruals, we find there is no evidence that institutional investors misprice normal accruals, while the individual investors overprice normal accruals. Our results suggest that institutional investors' superiority in mitigating the mispricing of total accruals is mainly due to their accurate pricing of normal accruals, and the reason why institutional investors cannot fully eliminate mispricing of accruals is that they are partly misled by earnings management.
\end{abstract}

Keywords: Institutional Investors; Earnings Management; Mispricing; Accruals

\section{INTRODUCTION}

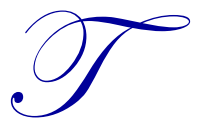

his study examines the role of institutional investors in the pricing of normal accruals and discretionary accruals, and whether they are misled by earnings management. Sloan (1996) demonstrates that investors overestimate the persistence of accruals causing the accruals to be overpriced; he further proposes that the mispricing of accruals is due to earnings fixation by naïve investors (e.g., individual investors). Recent evidence suggests that even sophisticated participants of the stock market such as institutional investors, financial analysts and auditors also misprice the accruals (Ali et al., 2000; Bradshaw et al., 2001; Collins et al., 2003), but institutional investors can significantly mitigate the extent of accruals' mispricing (Collins et al., 2003; Barone and Magilke, 2009). However, how institutional investors mitigate accruals mispricing and why they cannot fully eliminate accruals mispricing is still not clear. To answer these questions, we extend prior research (e.g., Xie, 2001; Collins et al., 2003) by decomposing total accruals into discretionary accruals and normal accruals. This decomposing enables us to investigate separately the effects of investor sophistication on: (1) normal accruals, which represent the "natural attribute" of total accruals; and (2) discretionary accruals, which represent the outcome of managerial earnings management. By comparing the pricing efficiency of institutional investors on these two types of accruals, we can better comprehend their superiority in pricing accruals, and what prevents them from fully and accurately pricing the accruals.

Following prior research (Sloan, 1996; Xie, 2001; Beneish and Vargus, 2002), we use the Mishkin (1983) test to address our research questions. The Mishkin test provides a statistical comparison between accruals' ability to predict one-year-ahead earnings (persistence) and investors' valuation of accruals' persistence. If the investors' valuation of accruals' persistence is higher than accruals' persistence, then the overpricing of accruals is indicated. Our analysis proceeds as follows. First, we compare the pricing between discretionary accruals and normal accruals. Second, we examine whether the extent of discretionary mispricing differs between firms with high institutional ownership and firms with low institutional ownership. The extent of normal accruals' mispricing difference is also 
examined. Third, we examine changes in institutional ownership in response to discretionary accruals and normal accruals. These analyses are based on the sample of listed Chinese (A-share) firms from 2001 and 2010.

Our persistence tests reveal that the normal accruals are significantly more persistent than the discretionary accruals. This result provides evidence that the earnings management will lower the persistence of accruals. The results of the pricing test are as follows. 1) The mispricing of the discretionary is greater than normal accruals, indicating that the mispricing of total accruals is due largely to the earnings management. 2) With respect to normal accruals, we find there is no evidence that institutional investors misprice these accruals, while the individual investors overprice normal accruals; we conjecture that the institutional investors' superiority to mitigate the mispricing of total accruals is mainly due to their accurate pricing of normal accruals. 3) Both individual investors and institutional investors significantly overprice discretionary accruals, while the extent of mispricing for institutional investors is significantly lower than that of individual investors; our findings indicate that the reason why institutional investors cannot fully eliminate accruals mispricing is that they are partly misled by the earnings management; 4) Institutional ownership changes are negatively related to accruals, indicating that institutional investors will sell stocks in response to high accruals. We also find that institutional investors are more sensitive to normal accruals than to discretionary accruals.

Our study provides some of the first insights into which type of accruals institutional investors tend to misprice, and help us in better understanding the role of institutional investors in accruals' mispricing. Taken together, our results support the naïve-investor hypothesis for the accruals anomaly, and show that earnings management is an important source of accruals mispricing for both individual investors and institutional investors in the context of the Chinese emerging capital market. Our results also provide useful information for institutional investor research, showing that the mitigating effect of institutional investors on accruals' mispricing is mainly due to their accurate pricing of normal accruals, and that institutional investors cannot fully understand the more complex discretionary accruals.

The rest of this paper is organized as follows. The next section reviews relevant literature and develops our hypothesis. In section 3, we describe our samples and data. In section 4, we present our main results and discuss our findings. The summary and limitations are in the final sections.

\section{LITERATURE REVIEW AND HYPOTHESIS DEVELOPMENT}

\subsection{The Mispricing of Accruals}

Accounting information plays a very important role in the capital market. However, Sloan (1996) finds that the market does not fully understand the information contained in the components of earnings (i.e., cash flow and accruals). Cash flow and accruals are different in the implication of future profitability; however, investors fail to understand this fact, so they overestimate the persistence of accruals, and therefore, overprice the accruals. A trading strategy that takes a long position of the low-accruals firms and a short position of the high-accruals firms can obtain a significant abnormal return in the following year. After Sloan (1996), a number of studies have examined the presence of an accruals anomaly (Thomas, 1999; Collins and Hribar, 2000; Bradshaw et al., 2001; Richardson et al., 2006). Pincus et al. (2007) document the existence of the accruals in four countries: Australia, Canada, the UK and the U.S. Adamek and Kaserer (2006) provide evidence that the accrual anomaly is also present in Germany. Lev and Nissim (2006) show that the accruals anomaly still persists since Sloan (1996) found it. As to China, Li et al. (2011) documents the presence of accrual mispricing in China's stock market.

Several studies provide numerous explanations for the accruals anomaly. Fairfield et al. (2003) document that the accruals are more highly correlated with invested capital, so the lower persistence of accruals stems from the effect of growth on future profitability. Some research focuses on the component of total accruals, such as special items or inventory changes. Dechow and Ge (2006) find that investors cannot fully appreciate the transitory nature of special items and showed that the special items are a significant contributing factor to low persistence of earnings in low-accruals firms. Richardson et al. (2006) provide evidence that the lower persistence of accruals was primarily due to temporary accounting distortions. Zhang (2007) investigates the growth and persistence hypotheses for the accruals anomaly, concluding that it is due to the fundamental investment information contained in accruals. 
Existing research also provides evidence that discretionary accruals are mispriced by investors. Teoh et al. (1998a, 1998b) and Rangan (1998) provide evidence that accruals are managed upwards to increase earnings in the year prior to and in the year of initial public offerings or seasoned equity offerings, and in such, investors overprice these discretionary accruals. Xie (2001) documents that the market overprices the persistence of abnormal accruals and the results show that the abnormal returns to the abnormal accruals-based hedge portfolio is significantly larger than the abnormal returns to the normal accruals-based hedge portfolio. Pincus et al. (2007) provide similar evidence in a global setting. Thomas and Zhang (2002) find that inventory changes can explain the negative relationship between accruals and future returns. They conjecture that earnings management masks the future profitability reversals due to inventory changes. Discretionary accruals are the result of the managerial earnings management, while normal accruals are the result of the normal operation activities. Thus, current earnings are less likely to persist if they mainly stem from the discretionary accruals and it is difficult for investors to recognize managerial earnings management. Therefore, our first hypothesis is as follows:

H1: The mispricing of discretionary accruals is greater than that of normal accruals.

\subsection{Institutional Investors and Accruals Mispricing}

Prior research often characterized institutional investors as sophisticated investors who can better understand firm's earnings component. Ke and Petroni (2004) find that transient institutional investors can predict a break in a string of consecutive quarterly earnings increase, thereby avoiding the forthcoming loss. They also provide evidence that institutional investors obtain information about forthcoming earnings breaks from managers through private communications. Jiambalvo et al. (2002) argue that institutional investors can better use both current-period information and non-earnings information to predict future earnings. Ali et al. (2004) find that changes in institutional ownership are related to abnormal returns at the time of the subsequent announcements of quarterly earnings, supporting that the institutional investors can trade based on information about forthcoming earnings.

A large body of empirical research also provides evidence that higher institutional ownership will lead to stock prices reflecting more earning information. Ayers and Freeman (2003) show that the price of firms with high institutional investors incorporates future earnings earlier than other firms. Piotroski and Roulstone (2004) find that institutional ownership can accelerate the future earnings news into prices. Collins et al (2003) show that firms with a high level of institutional ownership and a minimum threshold level of transient institutional investors have accruals that are more accurately priced. However, their research does not distinguish from where institutional investors' superior ability comes. Boehmer and Kelley (2009) study the relationship between institutional ownership and the relative informational efficiency of price, and their results show that both the institutional shareholdings and institutional trading activity can make stock prices become more efficient. Yan and Zhang (2009) investigated shortterm institutional investors and found consistent results with the notion that short-term institutional investors are better informed, and that they also trade actively to exploit their informational advantage. Barone and Magilke (2009) find evidence that is consistent with predictions of the naïve investors hypothesis, and their results show that mispricing is significant for naïve investors, while sophisticated institutional investors are associated with a significant reduction in the mispricing of cash flow. Deng and $\mathrm{Xu}$ (2011) document that institutional investors have better stock selection ability in China.

We focus on the pricing of normal accruals first. The normal accruals represent the adjustment of cash flow to earnings from the normal operational activities. Since institutional investors can better understand firms' earning component (Ali et al., 2004; Ke and Petroni, 2004; Jiambalvo et al., 2002) and higher institutional ownership leads to stock prices that reflect more earning information (Ayers and Freeman, 2003; Piotroski and Roulstone, 2004; Boehmer and Kelley, 2009; Yan and Zhang, 2009), we predict that the institutional investors can accurately price the persistence of normal accruals, while individual investors cannot accurately price the normal accruals. In such, we hypothesize:

H2: The normal accruals are overpriced for firms with low institutional ownership, while the normal accruals are accurately priced for firms with high institutional ownership. 
Prior research studies sophisticated investors' reaction to earnings management. Balsam et al. (2002) find that institutional investors play an important role in determining the timing of the market reaction to earnings management. Their results show that institutional investors can quickly respond to accruals management. They hypothesize that institutional investors have superior analytical skills, and can better decompose accruals into discretionary and normal components than individual investors. Another possibility is that the institutional investors have better information sources, such as conference calls and private conversations with management (Ke and Petroni, 2004), to allow them access to information that can help them to recognize earnings management more easily and/or quickly than individual investors. Therefore, we predict that institutional investors can better price the persistence of discretionary accruals than individual investors. However, the relationship between discretionary accruals and future earnings is more complex than the relationship between normal accruals and future earnings, so institutional investors may not fully eliminate the mispricing of accruals. This leads to our next hypothesis:

H3: The discretionary accruals are overpriced for both firms with low and high institutional ownership, while firms with high institutional ownership are associated with a significant reduction in this mispricing.

Following Collins (2003), we examine whether the differential accrual mispricing between individual investors and institutional investors is due to the institutional investors' trading based on accruals information. If the institutional investors are more sophisticated and better understand the accruals, then we expect the higher accruals (both discretionary accruals and normal accruals) will cause more institutional selling, making the accruals negatively related to the institutional ownership changes. Therefore, we propose the following hypothesis:

H4: The institutional ownership changes are negatively correlated with both the normal accruals and discretionary accruals.

\section{DATA AND SAMPLE}

\subsection{Sample Selection and Data Source}

We use all Chinese listed (A share) firms from 2001 to - 2010 as the initial sample. Financial statement data are collected from the CSMAR China Stock Market Financial Statements Database, return data are obtained from the CSMAR China Stock Market Trading Database, and institutional investor ownership data are collected from Wind Financial Database. Our sample begins in 2001 because the new accounting standard was released during that year. We exclude the financial firms (with an industry code of "I") because they have a different kind of financial statement.

\subsection{Measurement of the variables}

Similar to Collins (2003), we use the categorical classification instead of using a continuous measure to enhance the power of our tests. Firms with zero institutional ownership are grouped into the low institutional ownership subsample (hereafter "LIO"), and firms with institutional ownership higher than median are grouped into the high institutional ownership subsample (hereafter "HIO"). The final samples are 7,813 firm-years, with 2,854 firm-years in the HIO subsample and 4,959 firm-years in the LIO subsample.

We use the cross-sectional version of the Modified Jones (1991) Model that was presented by Defond and Jiambalvo (1994) to estimate normal accruals and discretionary accruals:

$$
\text { Accruals }_{t} / T A_{t}=a_{0} *\left(1 / T A_{t}\right)+a_{1} *\left(\Delta R E V_{t}-\Delta R E C_{t}\right) / T A_{t}+a_{2} *\left(P P E_{t} / T A_{t}\right)+e_{t}
$$

where accruals $s_{t}$ is the difference between net income before extraordinary items and net cash flow from operating activities; $\mathrm{TA}_{\mathrm{t}}$ is the average total asset in year $\mathrm{t}, \Delta \mathrm{REV}_{\mathrm{t}}$ is the change in sales revenues between year $\mathrm{t}-1$ and year $\mathrm{t}$; $\triangle \mathrm{REV}_{\mathrm{t}}$ is the change in account receivables between year $\mathrm{t}-1$ and year $\mathrm{t}$; and $\mathrm{PPE}_{\mathrm{t}}$ is gross property, plant and equipment. Following Xie (2001), we denote the predicted values of accruals from the Modified Jones Model as normal accruals (NAcc) and the residuals as discretionary accruals (DAcc). 
Table 1: Main Variable Definition

\begin{tabular}{ll}
\hline Variables & Definition and Measurement \\
\hline Earn & Net income before extraordinary items, scaled by average total asset \\
CFO & Net cash flow from operating activities, scaled by average total asset \\
Accruals & Accruals =Earn - CFO \\
NAcc & Normal accruals, the predicted values of accruals from the Modified Jones (1991) Model \\
DAcc & Discretionary accruals, the residuals from the Modified Jones Model \\
IO & Institutional Ownership=Sum of the institutional ownership \\
AR & Annual, size-adjusted, buy-and-hold returns from the beginning of the fifth month after the firm's \\
& fiscal year-end. \\
BM & Book-to-market ratio, the book value to market value. \\
Size & Natural logarithm of the market value of equity \\
\hline
\end{tabular}

Table 2 presents the descriptive statistics for the full sample and the LIO/HIO subsamples. Similar to Xie (2001) and Collins (2003), average accruals are negative (-0.017) and the discretionary accruals are near zero (0.003). Comparing the financial characteristics of firms between LIO and HIO, we find that the HIO subsample has better performance than the LIO subsample. For example, the earnings of the HIO subsample is 0.08 , which is higher than the earnings of the LIO subsample of 0.018; the HIO subsample also has more cash flow (0.086) than the LIO subsample (0.042), as with the accruals. However, the magnitude of normal accruals does not differ significantly across the two subsamples (-0.021 and -0,018). In the HIO subsample, the average institutional ownership is $21.261 \%$, which is far below the $63.6 \%$ reported by Collins (2003).

Table 2: Descriptive Statistics of Variables

\begin{tabular}{lccccccccc}
\hline Variables & $\begin{array}{c}\text { Full Sample } \\
\text { Mean }\end{array}$ & $\begin{array}{c}\text { LIO } \\
\text { Mean }\end{array}$ & $\begin{array}{c}\text { HIO } \\
\text { Mean }\end{array}$ & $\begin{array}{c}\text { Standard } \\
\text { Deviation }\end{array}$ & Min & Q1 & Median & Q3 & Max \\
\hline Earn $_{\mathrm{t}}$ & 0.041 & 0.018 & 0.08 & 0.081 & -0.307 & 0.012 & 0.038 & 0.072 & 0.319 \\
$\mathrm{CFO}_{\mathrm{t}}$ & 0.058 & 0.042 & 0.086 & 0.102 & -0.272 & 0.006 & 0.054 & 0.111 & 0.383 \\
Accruals $_{\mathrm{t}}$ & -0.017 & -0.024 & -0.006 & 0.109 & -0.368 & -0.071 & -0.021 & 0.028 & 0.388 \\
$\mathrm{DAcc}_{\mathrm{t}}$ & 0.003 & -0.002 & 0.012 & 0.106 & -0.439 & -0.046 & 0.002 & 0.049 & 0.471 \\
$\mathrm{NAcc}_{\mathrm{t}}$ & -0.020 & -0.021 & -0.018 & 0.028 & -0.126 & -0.038 & -0.023 & -0.006 & 0.135 \\
$\mathrm{AR}_{\mathrm{t}+1}$ & 0.021 & 0.031 & 0.002 & 0.342 & -1.196 & -0.16 & -0.038 & 0.117 & 1.704 \\
$\mathrm{IO}_{\mathrm{t}}$ & 7.767 & 0.000 & 21.261 & 13.904 & 0 & 0 & 0 & 10.681 & 64.041 \\
$\mathrm{BM}_{\mathrm{t}}$ & 0.365 & 0.335 & 0.428 & 0.284 & -0.726 & 0.191 & 0.317 & 0.506 & 1.393 \\
Size $_{\mathrm{t}}$ & 14.909 & 14.419 & 15.757 & 1.04 & 12.818 & 14.209 & 14.74 & 15.504 & 17.975 \\
\hline
\end{tabular}

Notes:

1: Full sample consists of 7,813 firm-years from 2001 to 2010, 4,959 firm-years for the HIO subsample, and 2,854 firm-years for the LIO subsample.

2: We do the $1 \%$ winsorization to the data to smooth the effect of outliers.

3: Statistics' significance at $1 \%, 5 \%$ and $10 \%$ levels are indicated by ***, ** and *, respectively (two-tail).

\section{RESEARCH DESIGN AND RESULTS}

\subsection{Institutional Ownership and Accruals Mispricing}

Following Sloan (1996), Xie (2001), and Beneish \& Vargus (2002), we use the framework proposed by Mishkin (1983) to test our hypotheses H1 H3. The Mishkin (1983) test is a two-stage rational expectations procedure, where the null hypothesis is that the investors rationally price the persistence of earnings components. Equation (2) is a forecasting equation to measure the persistence of the earnings component for predicting the oneyear-ahead earnings. Equation (3) is a pricing equation to estimate the valuation of persistence that the investors implicitly assign to the earnings component embedded in the stock price. Mispricing is indicated if the persistence of accruals is significantly different from the investors' perception of persistence for accruals. Specifically, following Beneish and Vargus (2002), we decompose total accruals into four parts and estimate the equations below:

$$
\begin{aligned}
& \text { Earn }_{t+1}=\beta_{0}+\beta_{1} L D A c c_{t}+\beta_{2} L N A c c_{t}+\beta_{3} H D A c c_{t}+\beta_{4} H N A c c_{t}+\beta_{5} C F O_{t}+\varepsilon_{t} \\
& A R_{t+1}=\delta_{0}+\delta_{1}\left[\operatorname{Earn}_{t+1}-\beta_{0}^{*}-\beta_{1}^{*} L D A c c_{t}-\beta_{2}^{*} L N A c c_{t}-\beta_{3}^{*} H D A c c_{t}-\beta_{4}^{*} H N A c c_{t}-\beta_{5}^{*} C F O_{t}\right]+z_{t}
\end{aligned}
$$


where:

LDAcc $=$ discretionary accruals if firm is in LIO subsamples, and 0 otherwise.

LNAcc $=$ normal accruals if firm is in LIO subsamples, and 0 otherwise.

HDAcc $=$ discretionary accruals if firm is in HIO subsamples, and 0 otherwise.

$\mathrm{HNAcc}=$ normal accruals if firm is in $\mathrm{HIO}$ subsamples, and 0 otherwise.

In Equations (2) and (3), the coefficients $\beta_{1}$ and $\beta_{2}$ capture the persistence of discretionary accruals and normal accruals for the LIO subsample, while the coefficients $\beta_{3}$ and $\beta_{4}$ capture the persistence of discretionary accruals and normal accruals for the HIO subsample. $\beta_{1}^{*}$ and $\beta_{2}^{*}$ capture the investors' perception of persistence for discretionary accruals and normal accruals in the LIO subsample, while $\beta_{3}{ }_{3}$ and $\beta_{4}{ }_{4}$ capture the investors' perception of persistence for discretionary accruals and normal accruals in the HIO subsample. We estimate Equations (2) and (3) jointly using a two-stage iterative generalized nonlinear least-squares procedure. In the first stage, Equations (2) and (3) are estimated without imposing any constraints; in the second stage, Equations (2) and (3) are estimated after imposing the rational pricing constraints to test whether the investors' perception of persistence (e.g., $\left.\beta_{1}^{*}\right)$ are significantly different from the persistence of earnings components (e.g., $\beta_{1}$ ) obtained from the first stage.

For the LIO subsample, we expect that both discretionary accruals and normal accruals will be overestimated, which means the valuation of persistence that investors implicitly assign to discretionary accruals and normal accruals are higher than the persistence of discretionary accruals and normal accruals for predicting oneyear-ahead earnings $\left(\beta_{1}<\beta^{*}{ }_{1}\right.$ and $\beta_{2}<\beta^{*}$ ). For the HIO subsample, we expect both discretionary accruals and normal accruals will be accurately priced, which means the valuation of persistence that investors implicitly assign to discretionary accruals and normal accruals are similar to the persistence of discretionary accruals and normal accruals for predicting one-year-ahead earnings $\left(\beta_{3} \approx \beta_{3}^{*}\right.$ and $\left.\beta_{4} \approx \beta_{4}{ }_{4}\right)$. According to Collins (2003), the ratio of persistence to perceived persistence (e.g. $\beta_{1} / \beta_{1}^{*}$ ) can be used as an efficiency ratio to compare the pricing efficiency between subsamples. If one component of accruals is mispriced by both the LIO subsample and the HIO subsample, we can use this ratio to compare the extent of the mispricing. If so, we predict that the ratio of HIO is bigger than the ratio of LIO, which means HIO can better price the persistence of accruals component.

Table 3: Mishkin Test for Market Pricing Results from Equation (2) and (3)

\begin{tabular}{|c|c|c|c|c|c|}
\hline \multicolumn{3}{|c|}{$\begin{array}{l}\operatorname{Earn}_{t+1}=\beta_{0}+\beta_{1} L D A c c_{t}+\beta_{2} L N A c c_{t}+\beta_{3} H D A c c_{t}+\beta_{4} H N A c c_{t}+\beta_{5} C F O_{t}+\varepsilon_{t} \\
A R_{t+1}=\delta_{0}+\delta_{1}\left[\operatorname{Earn}_{t+1}-\beta^{*}{ }_{0}-\beta^{*}{ }_{1} L D A c c_{t}-\beta_{2}{ }_{2} L N A c c_{t}-\beta^{*}{ }_{3} H D A c c_{t}-\beta^{*}{ }_{4} H N A c t_{t}-\beta_{5}^{*} C F O_{t}\right]+z_{t} \\
\text { Panel A: } \\
\text { Parameter Estimate } \\
\text { Parat }\end{array}$} & \multicolumn{3}{|c|}{$\begin{array}{l}\text { Test of Equality of Forecasting and } \\
\text { Pricing Coefficients }\end{array}$} \\
\hline Independent Variable & $\begin{array}{l}\text { Forecasting } \\
\text { Regression }\end{array}$ & $\begin{array}{l}\text { Pricing } \\
\text { Regression }\end{array}$ & \multicolumn{2}{|c|}{ Likelihood ratio } & p-value \\
\hline LDAcc & $\begin{array}{l}0.337 * * * \\
(30.21)\end{array}$ & $\begin{array}{l}0.962 * * * \\
(13.45)\end{array}$ & $\beta_{1}=\beta_{1}^{*}$ & 74.54 & 0.000 \\
\hline LNAcc & $\begin{array}{l}0.563^{* * *} \\
(15.46)\end{array}$ & $\begin{array}{l}0.971 * * * \\
(4.89)\end{array}$ & $\beta_{2}=\beta_{2}^{*}$ & 4.09 & 0.043 \\
\hline HDAcc & $\begin{array}{l}0.448 * * * \\
(28.36)\end{array}$ & $\begin{array}{l}0.86^{* * * *} \\
(9.65)\end{array}$ & $\beta_{3}=\beta_{3}^{*}$ & 20.71 & 0.000 \\
\hline HNAcc & $\begin{array}{l}0.522 * * * \\
(13.08)\end{array}$ & $\begin{array}{l}0.486^{* * *} \\
(2.25)\end{array}$ & $\beta_{4}=\beta_{4}^{*}$ & 0.03 & 0.870 \\
\hline $\mathrm{CFO}$ & $\begin{array}{l}0.528 * * * \\
(47.3) \\
\end{array}$ & $\begin{array}{l}0.782 * * * \\
(12.52) \\
\end{array}$ & $\beta_{5}=\beta_{5}^{*}$ & 15.94 & 0.000 \\
\hline Panel B: Coefficients Test: & Test Statistic & p-value & & & \\
\hline $\begin{array}{l}\text { Is the persistence of } \mathrm{LIO} / \mathrm{HIO} \\
\beta_{1}=\beta_{2} \\
\beta_{3}=\beta_{4}\end{array}$ & $\begin{array}{l}\text { normal accruc } \\
37.04 \\
3.42\end{array}$ & $\begin{array}{l}\text { from the persistence of } \mathrm{LIO} / \mathrm{H} \\
0.000 \\
0.064\end{array}$ & s discreti & accrua & \\
\hline $\begin{array}{l}\text { Is the pricing parameter of } L \\
\beta_{1}^{*}=\beta_{2}^{*} \\
\beta_{3}^{*}{ }_{3}^{*}=\beta_{4}^{*}\end{array}$ & $\begin{array}{l}\text { /HIO's normal } \\
0.00 \\
2.92\end{array}$ & $\begin{array}{l}\text { ifferent from the pricing parat } \\
0.963 \\
0.088\end{array}$ & of $L I O /$ & discret & uals? \\
\hline $\begin{array}{l}\text { Is the persistence of normal a } \\
\beta_{1} / \beta_{1}^{*}{ }_{1}=\beta_{2} / \beta_{2}^{*}\end{array}$ & $\begin{array}{l}\text { cruals different } \\
3.43\end{array}$ & $\begin{array}{l}\text { rsistence of discretionary acc } \\
0.064\end{array}$ & s in $L I O$ ? & & \\
\hline $\begin{array}{l}\text { Are the efficiency ratios of di } \\
\beta_{1} / \beta_{1}^{*}=\beta_{3} / \beta_{3}^{*}\end{array}$ & $\begin{array}{l}\text { retionary accru } \\
10.27\end{array}$ & $\begin{array}{l}\text { t between LIO and HIO? } \\
0.001\end{array}$ & & & \\
\hline
\end{tabular}


The results of the Mishkin test are presented in Table 3. The persistence of discretionary accruals is significantly lower than the persistence of normal accruals $\left(\beta_{1}=0.337<\beta_{2}=0.563, \mathrm{p}=0.000\right)$ for the LIO subsample, as with the HIO subsample $\left(\beta_{3}=0.448<\beta_{4}=0.522, p=0.064\right)$, which indicate that the persistence of discretionary accruals is lower than normal accruals. The pricing parameter of normal accruals and discretionary accruals for the LIO subsample are not different $\left(\beta^{*}{ }_{1}=0.962 \approx \beta_{2}{ }_{2}=0.971, \mathrm{p}=0.963\right)$, indicating that the individual investors may not distinguish the difference of persistence between normal accruals and discretionary accruals, as with the accruals and cash flow. For the HIO subsample, the situation is quite different. The pricing parameters are different $\left(\beta_{3}^{*}=0.860, \beta_{4}^{*}=0.486, \mathrm{p}=0.088\right)$, suggesting that the institutional investors may distinguish the difference of persistence. However, explaining these results must be done carefully, because $\beta_{3}^{*}$ is higher than $\beta_{4}^{*}$, which means that the institutional investors feel the discretionary accruals are more persistent than the normal accruals. We conjecture that the institutional investors may fully understand the implication of future earnings embedded in the normal accruals but they are misled by the earnings management, so that their valuation of persistence for discretionary accruals is higher.

Next, we shift our focus to the comparison of accruals' persistence with respect to future earnings and the investors' perceived persistence. In Panel A of Table 3, the persistence of normal accruals $\left(\beta_{2}\right)$ is 0.563 , while the investors' perceived persistence $\left(\beta_{2}{ }_{2}\right)$ is 0.971 , and $\beta_{2}=\beta_{2}^{*}$ is rejected, suggesting that the normal accruals are significantly overpriced in the LIO subsample. For the HIO subsample, we have $\beta_{4}=0.522$ and $\beta_{4}^{*}=0.486$ but $\beta_{4}=\beta^{*}{ }_{4}$ is not rejected, suggesting that the normal accruals are not mispriced in the HIO subsample. All in all, the result that LIO's normal accruals are mispriced and HIO's normal accruals are not mispriced fully support our hypothesis H2, indicating that the institutional investors can better price the normal accruals.

The pricing tests of discretionary accruals yield the following. For the LIO subsample, the persistence of discretionary accruals $\left(\beta_{1}\right)$ is 0.337 , which is significantly lower than the investors' perceived persistence $\left(\beta_{1}^{*}=0.962\right)$, and $\beta_{1}=\beta^{*}{ }_{1}$ is rejected, suggesting that the discretionary accruals are significantly overpriced in the LIO subsample. For the HIO subsample, $\beta_{3}=0.448, \beta_{3}{ }_{3}=0.86$ and $\beta_{3}=\beta_{3}{ }_{3}$ are rejected, suggesting that there exists significant discretionary accruals overpricing in the HIO subsample. This result is slightly different from the results obtained by Collins (2003); their results show that there is no significant mispricing of total accruals for the High Institutional Ownership firms. To gain further insight about the mispricing of discretionary accruals, we compare the pricing efficiency between LIO and HIO. The pricing efficiency ratio of discretionary accruals for $\operatorname{HIO}\left(\beta_{3} / \beta_{3}^{*}=0.521\right)$ is significantly higher $(\mathrm{p}=0.001)$ than that of LIO $\left(\beta_{1} / \beta^{*}{ }_{1}=0.350\right)$, indicating that although the HIO subsample also overestimates the discretionary accruals, the level of the overestimation is much lower than that of the LIO subsample. Thus, our hypothesis H3 is supported.

Finally, we compare the mispricing of the normal accruals and discretionary accruals. For the LIO subsample, the pricing efficiency ratio of discretionary accruals $\left(\beta_{1} / \beta^{*}{ }_{1}=0.350\right)$ is significantly lower than normal accruals $\left(\beta_{2} / \beta_{2}{ }_{2}=0.580\right)$; for the HIO subsample, the discretionary accruals are mispriced, while the normal accruals are accurately priced. Taken together, the results show that the mispricing of the discretionary accruals is greater than the mispricing of normal accruals, supporting our hypothesis H1, and indicating that the accruals' mispricing is due largely to the earnings management.

\subsection{Institutional Investors' Trading Behavior in Response to Normal Accruals and Discretionary Accruals}

To further examine whether the differential accrual mispricing between the LIO and HIO subsamples is due to the institutional investors' trading behavior based on accruals information, we investigate the relationship between changes in institutional ownership from year $\mathrm{t}-1$ to year $\mathrm{t}$ and the accruals at year $\mathrm{t}-1$. If institutional investors can understand the accruals' future earnings implications, which means high accruals related to future earnings reversal, they will sell stocks with high accruals. Hence, we expect a negative relationship between changes in institutional ownership and last year's accruals. Following Collins (2003), we use Equations (4) and (5) to test our hypothesis, H4. In Equation (4), C_IO represents the institutional ownership changes from year t-1 to year t. The control variables include Book-to-Market ratio, size and industry dummies. Other variables are as defined previously. We decompose total accruals into discretionary accruals and normal accruals in Equation (5) to see whether the institutional investors have a different response to different types of accruals. 


$$
\begin{aligned}
& C_{-} I O_{t}=a_{0}+a_{1} * \text { Accruals }_{t-1}+\Sigma \text { Control }+\varepsilon \\
& C_{-} I O_{t}=a_{0}+a_{1} * D A c c_{t-1}+a_{2} * N A c c_{t-1}+\Sigma \text { Control }+\varepsilon
\end{aligned}
$$

Table 4: Regressions of Changes in Institutional Ownership on Accruals

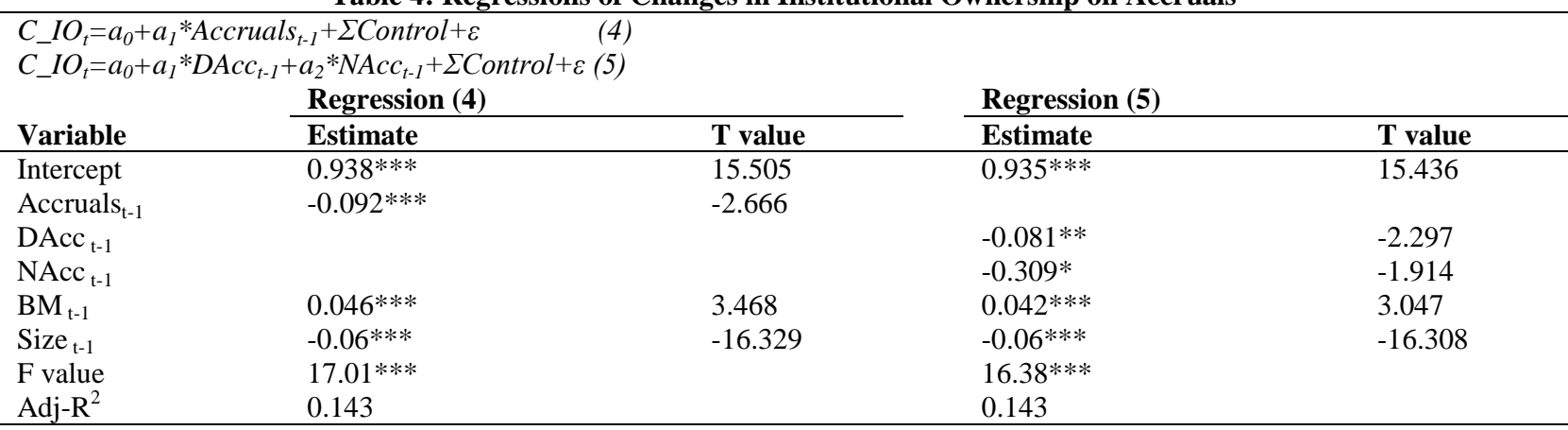

Notes:

1: $\mathrm{C}_{-} \mathrm{IO}$ is the changes in institutional ownership, equal to $\mathrm{IO}_{\mathrm{t}}$ minus $\mathrm{IO}_{\mathrm{t}-1}$.

2: Statistical significance at $1 \%, 5 \%$ and $10 \%$ levels are indicated by $* * *, * *$ and $*$, respectively (two-tail).

Table 4 reports the result from estimating Equations (4) and (5). Coefficient estimates of accruals, discretionary accruals and normal accruals are all significantly negative, indicating that institutional investors will sell stocks in response to high accruals, which support our hypothesis H4. Additionally, recall that results from Table 3 show that the persistence of normal accruals is higher than discretionary accruals, but the magnitude of DAcc's coefficient ( $\left.a_{1}=-0.081\right)$ in Equation (5) is smaller than NAcc's coefficient $\left(a_{2}=-0.309\right)$, which shows that the institutional investors have a greater response to normal accruals than to discretionary accruals. This result is consistent with the notion that the institutional investors are not always fully sophisticated and they also could be misled by the earnings management.

\section{CONCLUSION}

This paper examines the association between investor sophistication and the mispricing of discretionary accruals and normal accruals using a sample of listed Chinese (A-Share) firms from 2001 to 2010. By explicitly decomposing total accruals into normal accruals, which come from the normal activities of the firm, and discretionary accruals, which come from the managerial earnings management, we are able to investigate the different responses made by investors to these accruals. Following prior research, we employ the Mishkin (1983) test of rational expectation to empirically test whether the investors rationally price the persistence of normal accruals and discretionary accruals. The results show that: 1) the mispricing of discretionary accruals is more severe than the mispricing of normal accruals; 2 ) for normal accruals, the institutional investors accurately price the normal accruals, while the individual investors overprice the normal accruals; 3) for discretionary accruals, both institutional investors and individual investors overestimate the discretionary accruals, while institutional investors are associated with a significantly smaller overpricing; and 4) changes in institutional ownership are more related to the normal accruals rather than the discretionary accruals, showing that institutional investors cannot fully see through earnings management. In sum, our findings support the naïve-investor hypothesis for the accruals anomaly, as sophisticated institutional investors mitigate the mispricing of both discretionary accruals and normal accruals. We also find that institutional investors are partly misled by earnings management.

This paper contributes to accruals anomaly research by providing more evidence of the effect of investor sophistication on different components of the accruals. In addition, we show that earnings management is an important source of accruals mispricing for both individual investors and institutional investors. Our findings also have implications for institutional investor research. Although prior research has documented the fact that institutional investors can mitigate accruals' mispricing, we provide more direct evidence about the edge of institutional investors' superiority in the Chinese stock market: namely, that they can understand the normal accruals 
but they cannot fully understand the discretionary accruals from earnings management, which are more complicated than normal accruals.

\section{ACKNOWLEDGEMENTS}

This work is supported by the National Science Foundation of China (Grant No. 71172186, 71102095 \& 70902068).

\section{AUTHOR INFORMATION}

Zhen Zeng is a doctoral student in accounting in the School of Management at Xi'an Jiaotong University. His main research interests include accruals anomaly, institutional investors, and insider trading. E-mail: tsengmingchen@gmail.com; zengzhen@live.com

Dr. Peiyu Ou is an assistant professor of accounting in the School of Management at Xi' an Jiaotong University. Her main research interests include corporate governance and management accounting, and she is currently leading the research project (No. 70902068) funded by National Natural Science Foundation of China. E-mail: oupeiyu@mail.xjtu.edu.cn (Corresponding author)

Dr. Bin Li is an assistant professor of accounting in the School of Economics and Finance at Xi'an Jiaotong University. His main research interests include real earnings management, and he is currently leading the research project (No. 71102095) funded by National Natural Science Foundation of China. E-mail: libin2010@mail.xjtu.edu.cn

\section{REFERENCE}

1. Adamek, C. V., \& Kaserer, C. (2008). The Accrual Anomaly Under Different Accounting Standards Lessons Learned from the German Experiment. Journal of Business Finance \& Accounting, 35(7-8), 837859.

2. Ali, A., Durtschi, C., Lev, B., \& Trombley, M. (2004). Changes in Institutional Ownership and Subsequent Earnings Announcement Abnormal Returns. Journal of Accounting, Auditing \& Finance, 19, 221-248.

3. Ashiq Ali, D. D., Lee-Seok, H., \& Trombley, M. A. (2000). Accruals and Future Stock Returns: Tests of the Naive Investor Hypothesis. Journal of Accounting, Auditing \& Finance, 15, 161-181.

4. Ayers, B. C., \& Freeman, R. N. (2003). Evidence that Analyst Following and Institutional Ownership Accelerate the Pricing of Future Earnings. Review of Accounting Studies, 8(1), 47-67.

5. Balsam, S., Bartov, E., \& Marquardt, C. (2002). Accruals Management, Investor Sophistication, and Equity Valuation: Evidence from 10-Q Filings. Journal of Accounting Research, 40(4), 987-1012.

6. Barone, G. J., \& Magilke, M. J. (2009). An Examination of the Effects of Investor Sophistication on the Pricing of Accruals and Cash Flows. Journal of Accounting, Auditing \& Finance, 24, 385-414.

7. Boehmer, E., \& Kelley, E. K. (2009). Institutional Investors and the Informational Efficiency of Prices. The Review of Financial Studies, 22(9), 3563-3594.

8. Bradshaw, M. T., Richardson, S. A., \& Sloan, R. G. (2001). Do Analysts and Auditors Use Information in Accruals? Journal of Accounting Research, 39(1), 45-74.

9. Collins, D. W., Gong, G. J., \& Hribar, P. (2003). Investor Sophistication and the Mispricing of Accruals. Review of Accounting Studies, 8(2-3), 251-276.

10. Collins, D. W., \& Hribar, P. (2000). Earnings-based and accrual-based market anomalies: one effect or two? Journal of Accounting and Economics, 29(1), 101-123.

11. Dechow, P., \& Ge, W. (2006). The persistence of earnings and cash flows and the role of special items: Implications for the accrual anomaly. Review of Accounting Studies, 11(2), 253-296.

12. Deng, Y., \& Xu, Y. (2011). Do institutional investors have superior stock selection ability in China? China Journal of Accounting Research, 4(3), 107-119.

13. Fairfield, P. M., Whisenant, S., \& Yohn, T. L. (2003). The differential persistence of accruals and cash flows for future operating income versus future profitability. Review of Accounting Studies, 8(2-3), 221243. 
14. Jiambalvo, J., Rajgopal, S., \& Venkatachalam, M. (2002). Institutional Ownership and the Extent to which Stock Prices Reflect Future Earnings. Contemporary Accounting Research, 19(1), 117-145.

15. Ke, B., \& Petroni, K. (2004). How Informed Are Actively Trading Institutional Investors? Evidence from Their Trading Behavior before a Break in a String of Consecutive Earnings Increases. Journal of Accounting Research, 42(5), 895-927.

16. Lev, B., \& Nissim, D. (2006). The persistence of the accruals anomaly. Contemporary Accounting Research, 23(1), 193-226.

17. Li, Y., Niu, J., Zhang, R., \& Largay, J. A. (2011). Earnings Management and the Accrual Anomaly: Evidence from China. Journal of International Financial Management \& Accounting, 22(3), 205-245.

18. Messod, D. B., \& Mark, E. V. (2002). Insider trading, earnings quality, and accrual mispricing. The Accounting Review, 77(4), 755.

19. Pincus, M., Rajgopal, S., \& Venkatachalam, M. (2007). The Accrual Anomaly: International Evidence. Accounting Review, 82(1), 169-203.

20. Piotroski, J. D., \& Roulstone, D. T. (2005). Do insider trades reflect both contrarian beliefs and superior knowledge about future cash flow realizations? Journal of Accounting and Economics, 39(1), 55-81.

21. Rangan, S. (1998). Earnings management and the performance of seasoned equity offerings. Journal of Financial Economics, 50(1), 101-122.

22. Richardson, S. A., Sloan, R. G., Soliman, M. T., \& Tuna, I. (2006). The Implications of Accounting Distortions and Growth for Accruals and Profitability. The Accounting Review, 81(3), 713-743.

23. Sloan, R. G. (1996). Do Stock Prices Fully Reflect Information in Accruals and Cash Flows About Future Earnings? Accounting Review, 71(3), 289-315.

24. Teoh, S. H., Welch, I., \& Wong, T. J. (1998a). Earnings Management and the Long-Run Market Performance of Initial Public Offerings. The Journal of Finance, 53(6), 1935-1974.

25. Teoh, S. H., Welch, I., \& Wong, T.J. (1998b). Earnings management and the underperformance of seasoned equity offerings. Journal of Financial Economics, 50(1), 63-99.

26. Thomas, J. K., \& Zhang, H. (2002). Inventory Changes and Future Returns. Review of Accounting Studies, 7(2-3), 163-187.

27. Thomas, W. B. (1999). A test of the market's mispricing of domestic and foreign earnings. Journal of Accounting and Economics, 28(3), 243-267.

28. Xie, H. (2001). The Mispricing of Abnormal Accruals. The Accounting Review, 76(3), 357-373.

29. Yan, X., \& Zhang, Z. (2009). Institutional Investors and Equity Returns: Are Short-Term Institutions Better Informed? The Review of Financial Studies, 22(2), 893-924.

30. Zhang, X. F. (2007). Accruals, investment, and the accrual anomaly. Accounting Review, 82(5), $1333-1363$. 